\title{
Pattern of Chromosome 16q Loss Differs between an Atypical Proliferative Lesion and an Intraductal or Invasive Ductal Carcinoma Occurring Subsequently in the Same Area of the Breast
}

\author{
Hitoshi Tsuda, M.D., Teruko Takarabe, C.T., Sadako Akashi-Tanaka, M.D., Takashi Fukutomi, M.D, \\ Setsuo Hirohashi, M.D. \\ Pathology Division, National Cancer Center Research Institute (HT, TT, SH); and Department of Surgical \\ Oncology, National Cancer Center Hospital (SA, TF), Tokyo, Japan.
}

\begin{abstract}
Atypical proliferative lesions of the breast, such as atypical ductal hyperplasia and atypical papilloma, are considered to be precursors of breast carcinomas and have frequently been shown to have loss of heterozygosity $(\mathrm{LOH})$ on chromosome $16 \mathrm{q}$ at the DNA level. We evaluated whether an atypical proliferative lesion and a carcinoma that subsequently occurred in the same area of the ipsilateral breast were of identical clonal origin in seven patients. Using DNA isolated from microdissected archival tissue of epithelial components of both the biopsy specimen of the atypical proliferative lesion and the mastectomy specimen of the carcinoma, the pattern of LOH on 16q was compared between these two lesions using polymerase chain reaction -microsatellite LOH analysis. As a control, LOH on $16 \mathrm{q}$ was examined in 13 cases of usual ductal hyperplasia, 10 usual papillomas, and 6 atypical ductal hyperplasias. In the seven cases, $\mathrm{LOH}$ on $16 \mathrm{q}$ was detected in three of the six atypical proliferative lesions and in five of the seven carcinomas, but the allele with LOH or a deleted region always differed between the two. LOH was detected in both atypical proliferative lesions and carcinomas in one case, only in the atypical proliferative lesion in two cases, and only in carcinomas in three cases. In the controls, LOH on 16q was absent in usual ductal hyperplasias or usual papillomas but was detected in two of six atypical
\end{abstract}

Copyright (C) 2001 by The United States and Canadian Academy of Pathology, Inc.

VOL. 14, NO. 5, P. 382, 2001 Printed in the U.S.A.

Date of acceptance:

HT is currently affiliated with the Second Department of Pathology, National Defense Medical College.

This work was supported in part by a grant-in-aid from the Ministry of Health and Welfare, Japan.

Presented at the 91st Annual Meeting of the American Association for Cancer Research, San Francisco, California, April 1-5, 2000.

Address reprint requests to: Hitoshi Tsuda, M.D., Second Department of Pathology, National Defense Medical College, 3-2 Namiki, Tokorozawa, Saitama 359-8513, Japan; e-mail: htsuda@cc.ndmc.ac.jp; fax: 81-42-996-5193. ductal hyperplasias. Although atypical proliferative lesions were frequently confirmed to be of clonal nature with LOH on 16q, these lesions and carcinomas were considered to be clones, probably originated from a field with these clones.

KEY WORDS: Breast cancer, Chromosome 16, Loss of heterozygosity, Natural history, Precancer lesions.

Mod Pathol 2001;14(5):382-388

Intraductal carcinomas, or ductal carcinomas in situ (DCIS), are considered to be the early, preinvasive stage of breast cancer, and, if followed up, are often found to progress eventually to invasive cancers $(1,2)$. DCIS are subclassified into low-grade noncomedo type (i.e., cribriform, papillary, and low-papillary types) and high-grade comedo type. Atypical ductal hyperplasia (ADH) is defined as a small lesion of atypical epithelial cells with structural atypia but where the degree of atypia is not sufficient to classify DCIS. ADH is a risk factor for breast cancer occurrence, which becomes four times as likely as in women without the lesion $(3,4)$. Therefore, $\mathrm{ADH}$ stands in an intermediate position both histologically and as a cancer risk factor between the hyperplasia without atypia and DCIS. Atypical papillomas, or papillomas with an atypical or borderline part, which are frequently the feature of multiple papillomas, are also shown often to be accompanied by cancer and/or to be a risk factor of breast cancer (5-7).

Loss of heterozygosity (LOH) on chromosome $16 \mathrm{q}$ frequently occurs in human breast cancers, including low-grade DCIS (8-11). ADH is also reported to show LOH frequently on chromosomes $16 q$ and $17 p$ (12). Therefore, $\mathrm{ADH}$ is demonstrated to be a monoclonal proliferation, although it is undetermined whether the $\mathrm{ADH}$ is a hyperplastic lesion or a lesion at the earliest stage of low-grade 
DCIS. On the other hand, these chromosomal alterations are rare or absent in usual ductal hyperplasias and usual intraductal papillomas (10, 13-15). Thus, $\mathrm{LOH}$ on $16 \mathrm{q}$ is assumed to be involved in the acquisition of clonal proliferative properties by mammary glandular epithelial cells at the very early developmental stage.

A comparison of the pattern of $\mathrm{LOH}$ among different lesions in an ipsilateral breast will reveal their clonal origin (16). Several studies revealed clonal identity between the components of DCIS and invasive carcinoma in identical tumors $(17,18)$. We often observe the metachronous occurrence of an atypical proliferative lesion, for example, $\mathrm{ADH}$ or atypical papilloma, and a carcinoma in the same breast in a patient. However, it is still unclear whether these atypical proliferative lesions are the direct precursors of carcinomas occurring later in the same area of the breast. In the present study, to clarify this subject, we examined LOH on 16q among the breast lesions metachronously resected from the same patients. Initially, these patients underwent excision of a breast tumor that was disclosed to be an ADH/atypical papilloma; 2.7 to 16.1 years later, the patients underwent a mastectomy because of primary breast cancers that occurred at the area of previous excisional biopsy. We isolated DNA from archival tissue blocks of both the previous atypical lesions and the later carcinomas by means of microdissection and compared the pattern of LOH by polymerase chain reaction (PCR)mediated microsatellite analyses between these lesions.

\section{MATERIALS AND METHODS}

\section{Diagnostic Criteria}

The criteria of usual ductal hyperplasia, or hyperplasia of usual type, and usual intraductal papilloma have been given in previous studies (7, 13-15). The diagnosis of $\mathrm{ADH}$ was made according to the criteria of Page et al. $(3,19)$. The diagnosis of atypical papilloma was made if there were parts of borderline lesion or $\mathrm{ADH}$ within the papilloma $(3,6,7)$. In atypical papillomas, the part of borderline or $\mathrm{ADH}$ could be recognized solely on the basis of the relative homogeneity and hyperchromasia of the cellular mass. The histological type and grade of carcinomas were determined according to the criteria described by Page and Anderson $(20,21)$.

\section{Patients}

We selected 7 women who had undergone excision of a breast tumor diagnosed as an atypical proliferative lesion of duct epithelial cells (e.g., $\mathrm{ADH}$, atypical papilloma) and a subsequent mas- tectomy because of a primary breast carcinoma that had appeared at the site of previous biopsy. By reviewing hematoxylin and eosin (HE)-stained tissue sections, the histological diagnosis was confirmed.

\section{Case 1}

A left breast tumor was biopsied and diagnosed as atypical hyperplasia. This lesion was confirmed as compatible with ADH (Fig. 1, A-B). After 16 years, the patient noticed a $2.8 \times 2.5-\mathrm{cm}$ tumor at the site of the previous biopsy. The tumor was diagnosed as invasive ductal carcinoma (IDC), solid-tubular type, Grade 3 (Fig. 1C), and a modified radical mastectomy was performed.

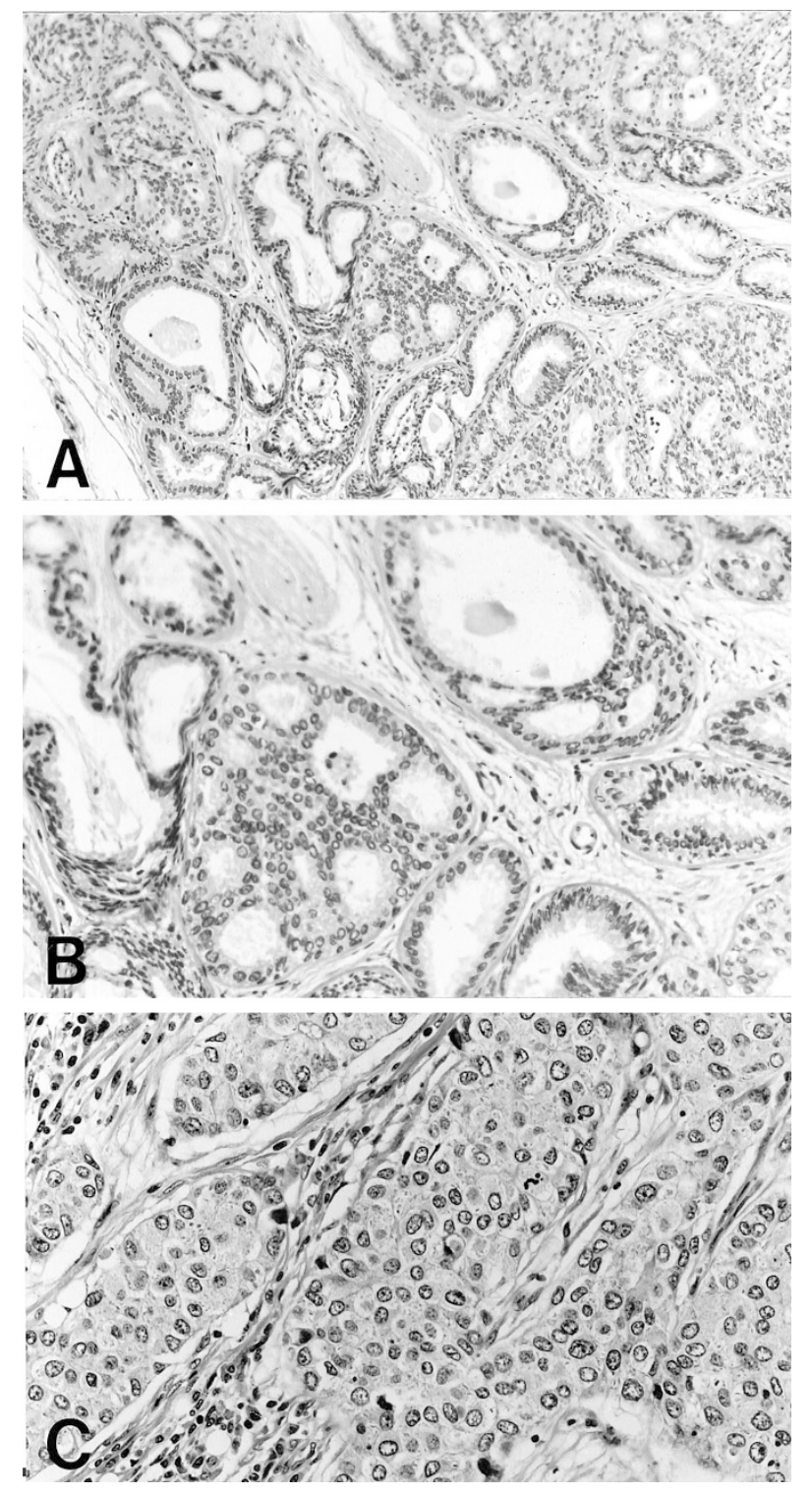

FIGURE 1. Histological presentation of an atypical hyperplastic lesion and a carcinoma resected metachronously from Patient 1. (A, B) Earlier atypical ductal hyperplasia $(\mathbf{A}, \times 100 ; \mathbf{B}, \times 200)$ and $(\mathbf{C})$ later invasive ductal carcinoma $(\times 200)$. Hematoxylin and eosin staining. 


\section{Case 2}

A 56-year-old woman underwent excisional biopsy of a right breast tumor, which was diagnosed as atypical hyperplasia. The lesion was slightly atypical duct papillomatosis and was included in the category of $\mathrm{ADH}$. After 5.5 years, she noticed a right-breast tumor $(1.8 \times 2.0 \mathrm{~cm})$ at the biopsy site during a follow-up exam. She underwent a mastectomy and was diagnosed to have an IDC with a DCIS component and another incidental lobular carcinoma in situ.

\section{Case 3}

A 33-year-old woman underwent excisional biopsy of a right breast tumor measuring $2.5 \times 2.0$ $\mathrm{cm}$. The tumor was diagnosed as atypical intraductal papilloma and confirmed as such by review (Fig.
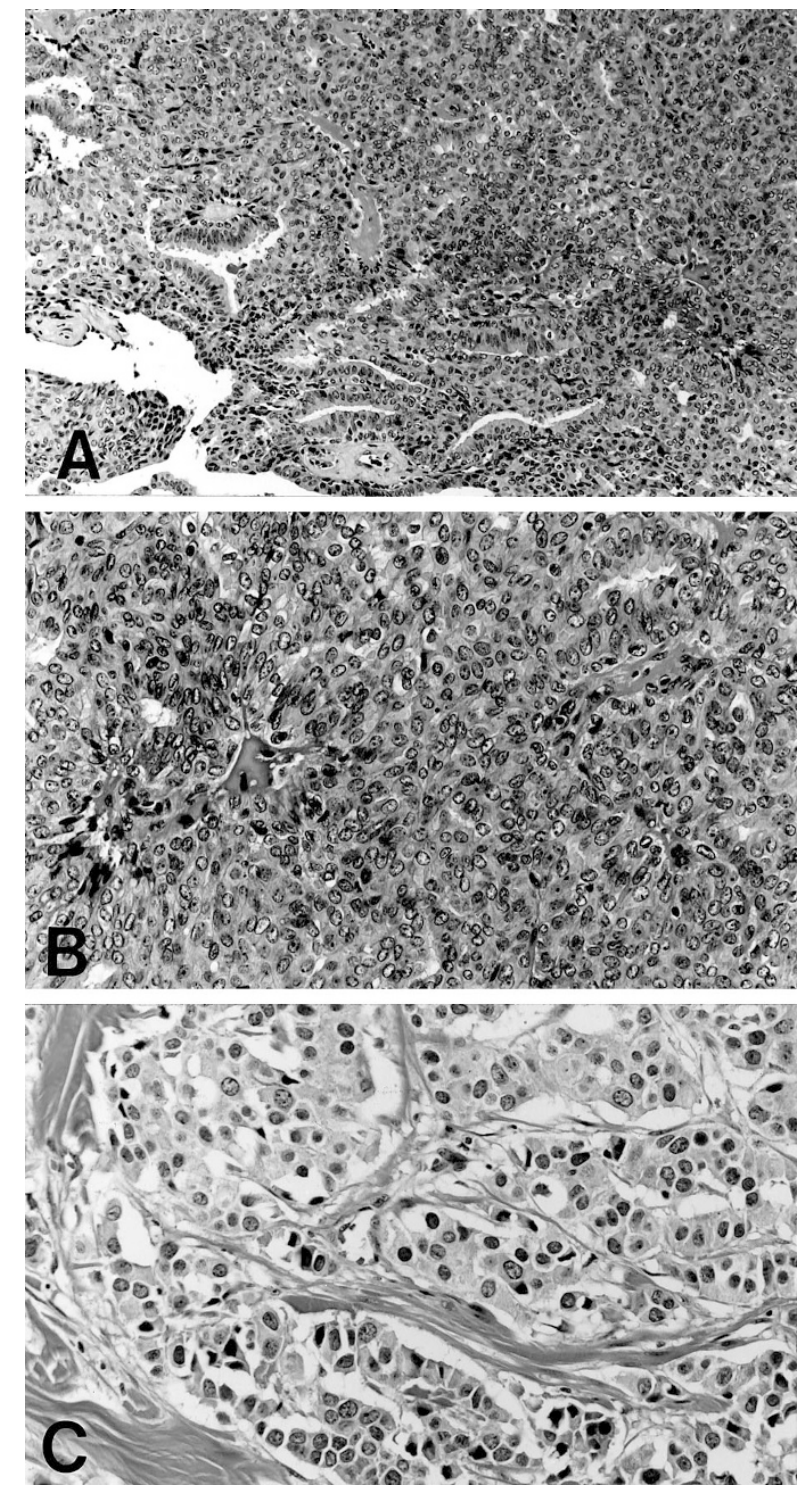

FIGURE 2. Histological presentation of an atypical hyperplastic lesion and a carcinoma resected metachronously from Patient 3. (A, B) Earlier atypical papilloma $(\mathbf{A}, \times 100 ; \mathbf{B}, \times 200)$ and $(\mathbf{C})$ later invasive ductal carcinoma $(\times 200)$. Hematoxylin and eosin staining.
2 , A-B). Sixteen years later, she visited the hospital complaining of a very large $(10-\mathrm{cm})$ tumor occupying the right breast, including the biopsy site, and after diagnosis of IDC, scirrhous type, Grade 3, she underwent a mastectomy and adjuvant chemotherapy (Fig. 2C).

\section{Case 4}

A 42-year-old-woman underwent excisional biopsy of a right breast tumor after complaining of bloody nipple discharge; this tumor was diagnosed as atypical papilloma (borderline case). A review showed the lesion to be equivocal between atypical papilloma and DCIS of low-papillary type. After 5.8 years, the patient noticed a tumor at the biopsy site and underwent a simple mastectomy after diagnosis of IDC, papillotubular type, Grade 2.

\section{Case 5}

A 45-year-old woman underwent excision of a left breast tumor, which was diagnosed as atypical hyperplasia. The lesion was confirmed to be ADH by review. After 11.2 years, she noticed another tumor at the biopsy site and underwent a mastectomy after diagnosis of DCIS with early invasion.

\section{Case 6}

A 53-year-old woman underwent a biopsy of a left breast tumor. After 5.3 years, a $3.2 \times 3.1-\mathrm{cm}$ tumor recurred at the same site. The previous lesion was diagnosed as atypical papilloma and the latter as IDC, papillotubular, Grade 2 (Fig. 3, A-C).

\section{Case 7}

A 58-year-old woman underwent a biopsy because of a left breast tumor, and after 2.7 years, she underwent a mastectomy because another tumor had occurred at the same site. The former was diagnosed as duct papillomatosis with atypia, which was categorized as mild $\mathrm{ADH}$ by review, whereas the latter was identified as IDC of scirrhous type with a DCIS component.

\section{Control Cases}

Among women who underwent excision of breast tissue because of tumor or abnormal nipple discharge at the National Cancer Center Hospital between 1986 and 1998, we randomly selected 13 cases of usual ductal hyperplasia, 10 cases of usual papilloma, and 6 cases of ADH. None of these lesions were accompanied by an ipsilateral, synchronous carcinoma, and all of them differed in location.

\section{Microdissection and DNA Extraction}

From the formalin-fixed paraffin-embedded tissue blocks of these lesions and tumors stored at the 


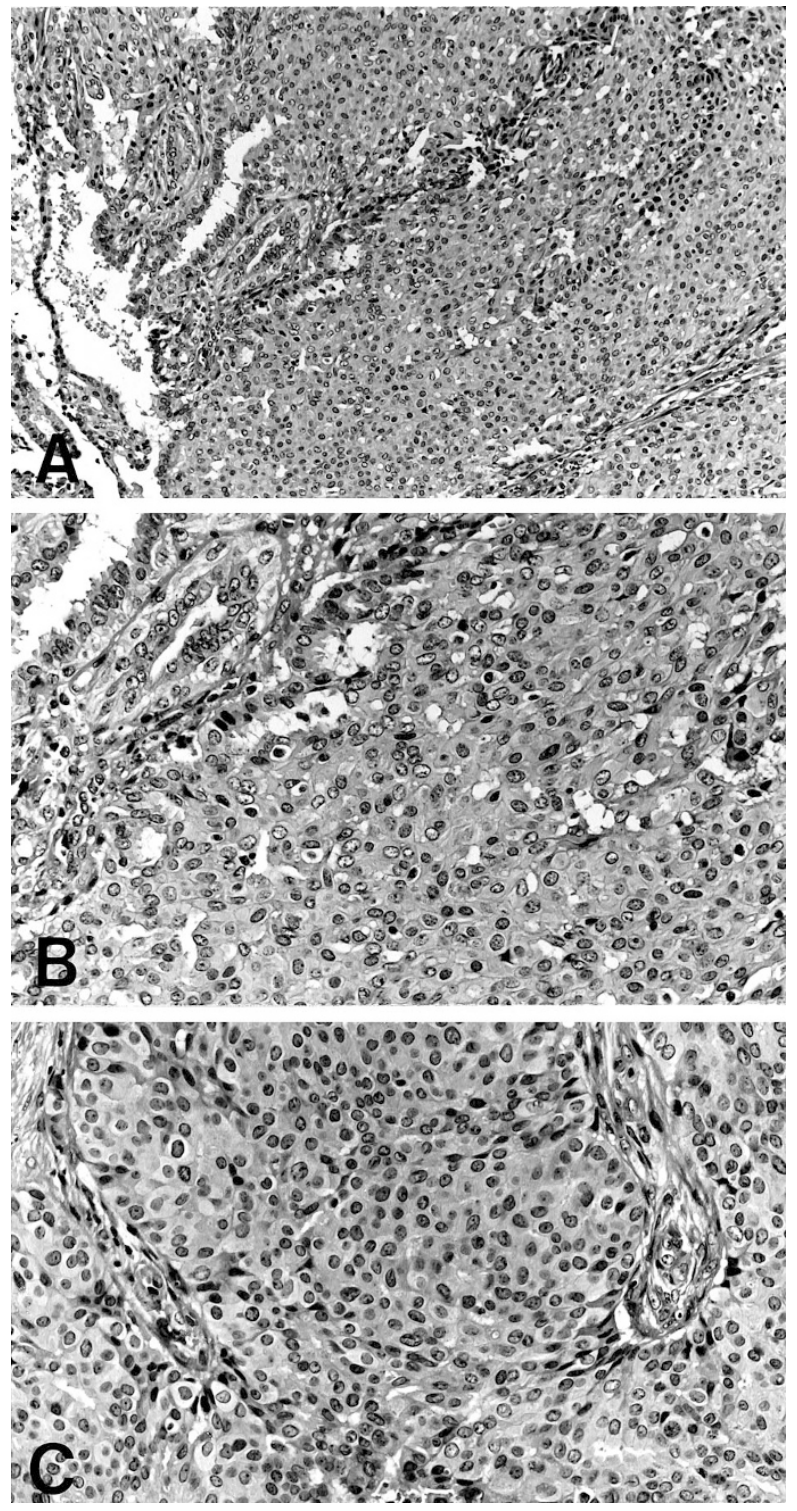

FIGURE 3. Histological presentation of an atypical hyperplastic lesion and a carcinoma resected metachronously from Patient 6. (A, B) Earlier atypical papilloma $(\mathbf{A}, \times 100 ; \mathbf{B}, \times 200)$ and $(\mathbf{C})$ later invasive ductal carcinoma (x200). Hematoxylin and eosin staining.

hospital, tissue sections were cut in $10-\mu \mathrm{m}$ thicknesses for the selective microdissection of the epithelial component of atypical lesions and carcinomas. The sections were mounted on noncoated glass slides and stained with HE.

Using LM200 laser capture microdissection (Arcturus Engineering, Santa Clara, CA), the epithelial component of the atypical lesions was collected from the HE-stained tissue sections (22). For normal DNA, adipose tissue or lymphocytes were dissected. From the collected tissue, DNA was isolated using a QiaAmp DNA mini kit (Qiagen, Basel, Switzerland) according to the supplier's recommendation. The DNA was dried up and dissolved in $100 \mu \mathrm{L}$ of 10 mm Tris- $\mathrm{HCl}$ ( $\mathrm{pH}$ 8.0)-1 mм EDTA.

\section{PCR-LOH Analysis}

For PCR, oligonucleotide primers were synthesized by Sawady Technology (Tokyo, Japan). The sense primer was labeled with 6-carboxyfluorescein. The primer sets used were D16S409 (q12.1), D16S304 (q12.1), D16S408 (q13), D16S514 (q21), D16S512 (q22), D16S515 (q22), D16S303 (q22), D16S518 (q23.3q24.1), D16S305 (q23-q24), and D16S393 (q23-q24) $(23,24)$. With $10 \mu \mathrm{L}$ of DNA, the final concentration of a $20-\mu$ L PCR reaction mixture comprised a $1 \times$ Gold PCR buffer; $2.5 \mathrm{~mm} \mathrm{MgCl}_{2} ; 112.5 \mu \mathrm{M}$ each dATP, dGTP, dCTP, and TTP; $4 \mu \mathrm{M}$ each primer; and $0.5 \mathrm{U}$ AmpliTaq Gold (Perkin-Elmer, Foster City, CA). This was subjected to PCR composed of 1 cycle at $95^{\circ} \mathrm{C}$ for 10 minutes, 35 cycles at $95^{\circ} \mathrm{C}$ for 30 seconds, $55^{\circ} \mathrm{C}$ for 30 seconds, and $72^{\circ} \mathrm{C}$ for 1 minute, followed by 1 cycle at $75^{\circ} \mathrm{C}$ for 5 minutes, using the GeneAmp PCR system 9600 (Perkin-Elmer). DNA products amplified by PCR were analyzed directly by an ABI Prism 310 genetic analyzer and a GeneScan Analysis software program (Perkin-Elmer). If the peak representing an allele in the lesion DNA was a third or less of the peak of the same allele in normal-cell DNA, the lesion was judged to have LOH. The PCR analysis was repeated twice, and when results were uncertain, the experiment was further repeated until the reliability of the results became convincing.

\section{RESULTS}

The results of the study of seven follow-up cases are summarized in Figure 4 and Table 1. In Patient $1, \mathrm{LOH}$ was detected in both the ADH and the IDC. LOH was commonly detected at the D16S514 and D16S393 loci but only in the IDC at D16S512. In Patient 2, LOH was detected in the DCIS that was

\begin{tabular}{|c|c|c|c|c|c|c|c|c|c|c|c|c|c|}
\hline \multirow{2}{*}{$\overline{\text { Case }}$} & \multicolumn{2}{|c|}{ Lesions } & \multirow{2}{*}{ Interval } & \multicolumn{5}{|c|}{ Chromosome markers } & \multirow{3}{*}{ S515 } & \multirow{3}{*}{$\frac{\mathrm{S} 303}{\mathrm{~N} 1}$} & \multirow{3}{*}{$\frac{S 518}{N D}$} & \multirow[b]{2}{*}{$\$ 305$} & \multirow[b]{2}{*}{$\mathrm{S} 393$} \\
\hline & & & & 5409 & 5304 & 5408 & $\$ 514$ & $\$ 512$ & & & & & \\
\hline \multirow[t]{2}{*}{1} & 1st & ADH & $16 \mathrm{yr}$ & $\mathrm{NI}$ & $\mathrm{NI}$ & $\mathrm{NI}$ & $\bullet$ & & & & & $\mathrm{ND}$ & $\bullet$ \\
\hline & 2nd & IDC & & NI & $\mathrm{NI}$ & $\mathrm{NI}$ & $\bullet$ & $\bullet$ & $\mathrm{NI}$ & $\mathrm{NI}$ & ND & ND & - \\
\hline \multirow{4}{*}{2} & $1 \mathrm{st}$ & ADH & $5.5 \mathrm{yr}$ & $\mathrm{NI}$ & $\mathrm{NI}$ & $\mathrm{NI}$ & $\mathrm{NI}$ & ; & $\mathrm{NI}$ & $\mathrm{NI}$ & ND & $\mathrm{NI}$ & $\mathrm{NI}$ \\
\hline & 2nd & DCIS & & $\mathrm{NI}$ & $\mathrm{NI}$ & $\mathrm{N} !$ & $\mathrm{NI}$ & $\bullet$ & $\mathrm{NI}$ & $\mathrm{NI}$ & NI & NI & $\mathrm{NI}$ \\
\hline & & $\mathrm{IDC}$ & & $\mathrm{NI}$ & $\mathrm{NI}$ & $\mathrm{N}$ & $\mathrm{NI}$ & NO & $\mathrm{NI}$ & $\mathrm{NI}$ & $\mathrm{NI}$ & $\mathrm{NI}$ & $\mathrm{NI}$ \\
\hline & & LCIS & & $\mathrm{NI}$ & $\mathrm{NI}$ & $\mathrm{N}$ & NI & 0 & $\mathrm{NI}$ & $\mathrm{NI}$ & ND & ND & $\mathrm{NI}$ \\
\hline \multirow[t]{2}{*}{3} & 1st & Atyp. & $16.1 \mathrm{yr}$ & e & $\mathrm{Nl}$ & ND & - & 0 & - & ND & $\mathrm{NI}$ & ND & - \\
\hline & 2nd & & & o & $\mathrm{NI}$ & o & o & 0 & o & ND & $\mathrm{NI}$ & ND & ND \\
\hline \multirow[t]{2}{*}{4} & $1 s t$ & apilloma & $5.8 \mathrm{yr}$ & ND & $\mathrm{NI}$ & 0 & - & ND & ND & $\mathrm{N} 1$ & $\mathrm{NI}$ & ND & $\bullet$ \\
\hline & 2nd & & & ND & $\mathrm{NI}$ & Q & 。 & ND & ND & $\mathrm{NI}$ & $\mathrm{NI}$ & ND & 0 \\
\hline \multirow[t]{2}{*}{5} & 1st & $\mathrm{ADH}$ & $11.2 \mathrm{yr}$ & $\mathrm{N}$ & $\mathrm{NI}$ & NO & 0 & ND & ND & ND & ND & $\mathrm{ND}$ & ND \\
\hline & 2nd & DCIS & & $\mathrm{Ni}$ & $\mathrm{NI}$ & ND & - & ND & ND & ND & ND & ND & ND \\
\hline \multirow[t]{2}{*}{6} & ist & Atyp. & $5.3 \mathrm{yr}$ & $\mathrm{NI}$ & $\mathrm{NI}$ & ND & 0 & & ND & NO & ND & o & ND \\
\hline & 2nd & & & $\mathrm{NI}$ & $\mathrm{NI}$ & N! & $\bullet$ & $\bullet$ & ND & ND & - & - & ND \\
\hline \multirow[t]{3}{*}{7} & 1st & $\mathrm{ADH}$ & $2.7 \mathrm{yr}$ & $\mathrm{NI}$ & $\mathrm{NI}$ & NI & $\mathrm{NI}$ & ND & NN & ND & ND & $\mathrm{NI}$ & ND \\
\hline & 2nd & DCIS & & $\mathrm{NI}$ & $\mathrm{NI}$ & $\mathrm{Nl}$ & $\mathrm{Nl}$ & ND & ND & ND & ND & $\mathrm{NI}$ & 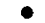 \\
\hline & & $I D C$ & & $\mathrm{Ni}$ & $\mathrm{NI}$ & $\mathrm{NI}$ & $\mathrm{NI}$ & ND & ND & $\bullet$ & ND & $\mathrm{NI}$ & 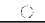 \\
\hline
\end{tabular}

FIGURE 4. A summary of microsatellite loss of heterozygosity (LOH) analysis in an atypical hyperplastic lesion and a carcinoma resected metachronously from seven patients. $\mathrm{ADH}$, atypical ductal hyperplasia; Atyp. Papilloma, atypical papilloma; DCIS, ductal carcinoma in situ; IDC invasive ductal carcinoma; LCIS, lobular carcinoma in situ. S409, S304, and so forth indicate loci of chromosome markers: D16S409, D16S304, and so forth; NI, not informative; ND, not done; $\bullet$ LOH; O, no LOH. 
resected later by mastectomy but not in previous biopsy specimens of the $\mathrm{ADH}$ and in the later lobular carcinoma in situ. In Patient 3, LOH was detected in the previously resected atypical papilloma but not in the IDC resected later (Fig. 5). The same results were observed for Patient 4 , in which the earlier low-papillary DCIS/atypical papilloma had $\mathrm{LOH}$, but the later IDC did not. In Cases 5 and 6, $\mathrm{LOH}$ was only detected in the carcinomas resected later but not in the previous $\mathrm{ADH}$ or atypical papilloma (Fig. 6). In Patient 7, data on $\mathrm{LOH}$ was not available for the $\mathrm{ADH}$.

$\mathrm{LOH}$ was absent at any loci on chromosome $16 \mathrm{q}$ examined in epithelial cells in the 13 usual ductal hyperplasias and 9 usual papillomas (Fig. 7). Only one usual papilloma was judged to have microsatellite instability at only one (D16S512) of the two informative loci. In the six ADH cases, two (33\%)
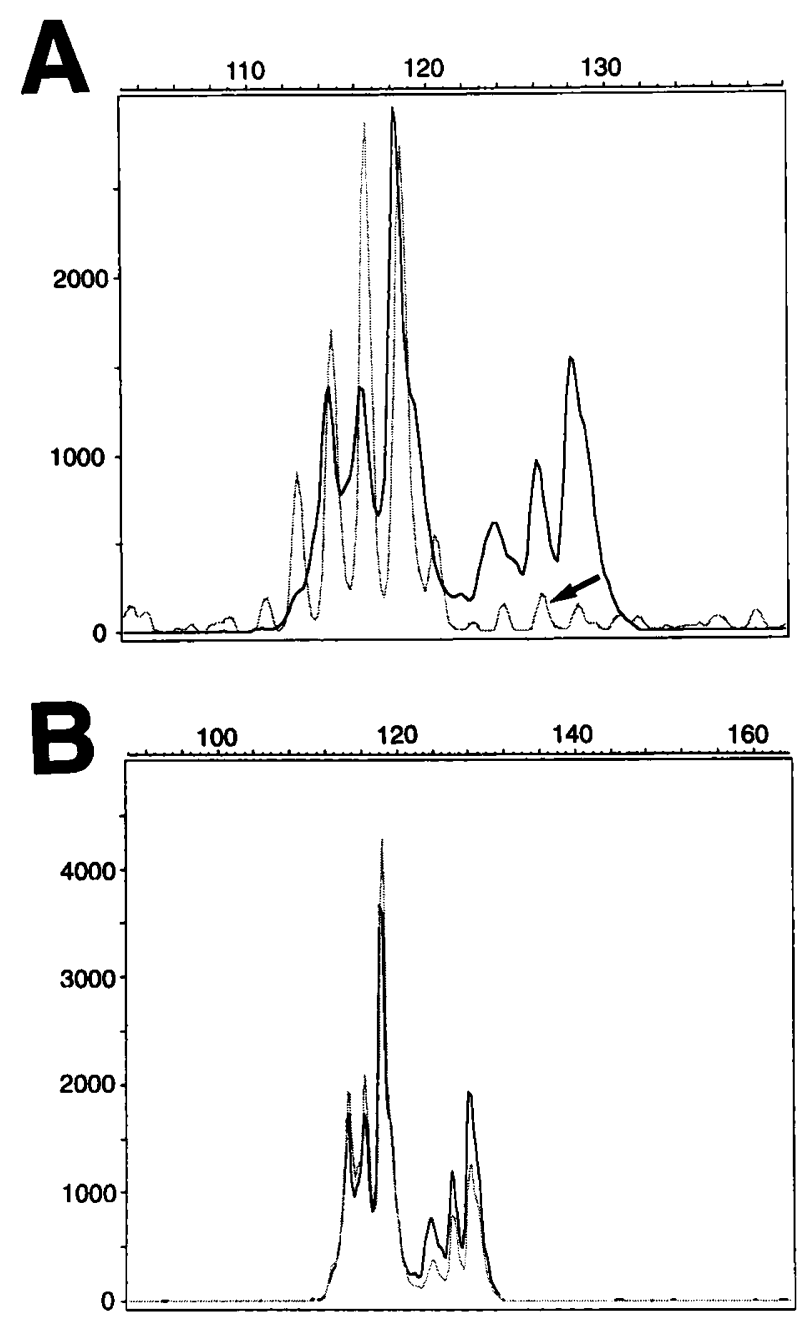

FIGURE 5. Loss of heterozygosity (LOH) on chromosome 16q in an atypical hyperplastic lesion and a carcinoma resected metachronously from Case 3. (A) Earlier atypical papilloma and (B) later ductal carcinoma. Abscissa, size of polymerase chain reaction (PCR) product; ordinates, intensity of fluorescence; darker curves, PCR products from normal cells; lighter curves, PCR products from cells of the atypical papilloma or carcinoma. LOH is detected only in the atypical papilloma (A, arrow).
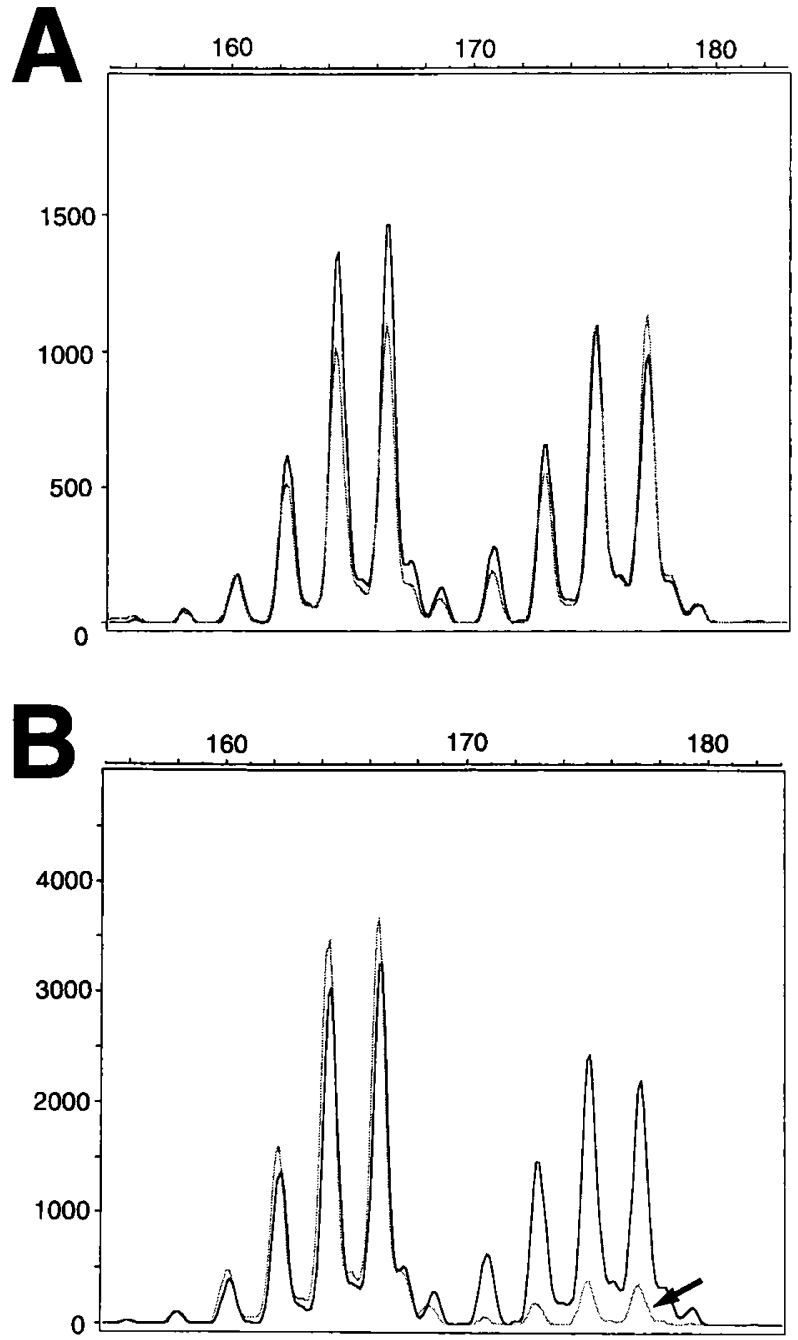

FIGURE 6. Loss of heterozygosity (LOH) on chromosome $16 \mathrm{q}$ in an atypical hyperplastic lesion and a carcinoma resected metachronously from Case 6. (A) Earlier atypical papilloma and (B) later ductal carcinoma. Abscissa, size of polymerase chain reaction (PCR) product; ordinates, intensity of fluorescence; darker curves, PCR products from normal cells; lighter curves, PCR products from cells of the atypical papilloma or carcinoma. LOH is detected only in the carcinoma (B, arrow).

revealed LOH on 16q: one (Case 25) had LOH at distal loci (D16S305 and D16S393) but not at a proximal site (D16S304). The other (Case 26) showed LOH at D16S512 and D16S393 but not at other loci.

\section{DISCUSSION}

$\mathrm{LOH}$ on chromosome $16 \mathrm{q}$ is frequently detected in both DCIS and invasive carcinomas of the breast, irrespective of histological grade or type (8-11). However, recent studies have disclosed that the statuses of chromosome 16 markedly differ between the group comprising noncomedo DCIS and low- to intermediate-grade invasive carcinomas and another group comprising comedo DCIS and high-grade invasive carcinomas. In the former 
$16 \mathrm{q}$ chromosome marker

\begin{tabular}{|c|c|c|c|c|c|c|c|c|c|c|}
\hline \multirow[b]{2}{*}{ Case/Age } & \multicolumn{10}{|c|}{$16 \mathrm{q}$ chromosome marker } \\
\hline & $\$ 409$ & $\mathrm{~S} 304$ & $\$ 408$ & S514 & $\mathrm{S} 512$ & S515 & $\mathrm{S} 303$ & S518 & S305 & $\mathrm{S} 393$ \\
\hline \multicolumn{11}{|l|}{ Hyperplasia } \\
\hline $1 / 50$ & ND & 0 & ND & $\mathrm{NI}$ & ND & ND & $\mathrm{NI}$ & ND & ND & $\mathrm{NI}$ \\
\hline 2/44 & ND & $\mathrm{NI}$ & ND & 0 & $\mathrm{NI}$ & ND & ND & ND & $\mathrm{NI}$ & $\mathrm{NI}$ \\
\hline $3 / 39$ & 0 & ND & ND & 0 & ND & $\mathrm{NI}$ & ND & ND & ND & $\mathrm{NI}$ \\
\hline $4 / 49$ & 0 & $\mathrm{NI}$ & ND & 0 & $\mathrm{~N} 1$ & $\mathrm{NI}$ & $\mathrm{NI}$ & ND & 0 & 0 \\
\hline $5 / 42$ & 0 & $\mathrm{NI}$ & $\mathrm{NI}$ & 0 & 0 & 0 & $\mathrm{NI}$ & 0 & 0 & 0 \\
\hline $6 / 47$ & $\mathrm{~N} 1$ & 0 & $\mathrm{NI}$ & $\mathrm{NI}$ & ND & $\mathrm{NI}$ & $\mathrm{NI}$ & ND & $\mathrm{NI}$ & 0 \\
\hline $7 / 44$ & ND & ND & ND & 0 & 0 & 0 & $\mathrm{NI}$ & $\mathrm{NI}$ & 0 & 0 \\
\hline $8 / 42$ & ND & $\mathrm{NI}$ & ND & $\mathrm{NI}$ & $\mathrm{NI}$ & $\mathrm{NI}$ & $\mathrm{NI}$ & 0 & $\mathrm{NI}$ & $\mathrm{NI}$ \\
\hline $9 / 31$ & ND & $\mathrm{NI}$ & $\mathrm{NI}$ & 0 & $\mathrm{NI}$ & 0 & & $\mathrm{NI}$ & 0 & $\mathrm{NI}$ \\
\hline $10 / 43$ & 0 & $\mathrm{NI}$ & $\mathrm{NI}$ & $\mathrm{NI}$ & $\mathrm{NI}$ & 0 & $\mathrm{NI}$ & 0 & $\mathrm{NI}$ & 0 \\
\hline $11 / 51$ & $\mathrm{NI}$ & $\mathrm{Ni}$ & 0 & 0 & $\mathrm{Nt}$ & 0 & $\mathrm{NI}$ & ND & $\mathrm{NI}$ & $\mathrm{NI}$ \\
\hline $12 / 49$ & $\mathrm{NI}$ & $\mathrm{N}$ & 0 & 0 & 0 & $\mathrm{NI}$ & $\mathrm{NI}$ & 0 & 0 & $\mathrm{NI}$ \\
\hline $13 / 49$ & ND & N] & 0 & $\mathrm{Ni}$ & $\mathrm{NI}$ & 0 & $\mathrm{NI}$ & 0 & 0 & 0 \\
\hline \multicolumn{11}{|l|}{ Papilloma } \\
\hline $14 / 50$ & ND & $\mathrm{NI}$ & ND & $\mathrm{NI}$ & $\mathrm{NI}$ & ND & ND & ND & $\mathrm{NI}$ & ND \\
\hline $15 / 43$ & 0 & 0 & ND & 0 & 0 & 0 & ND & ND & $\mathrm{NI}$ & $\mathrm{NI}$ \\
\hline $16 / 34$ & ND & $\mathrm{NI}$ & ND & $\mathrm{O}$ & M] & ND & ND & $\mathrm{NI}$ & $\mathrm{N} 1$ & ND \\
\hline $17 / 45$ & 0 & 0 & ND & 0 & ND & 0 & $\mathrm{NI}$ & 0 & $\mathrm{Nl}$ & 0 \\
\hline $18 / 47$ & $\mathrm{NI}$ & $\mathrm{NI}$ & $\mathrm{Nl}$ & 0 & ND & $\mathrm{NI}$ & ND & ND & $\mathrm{NI}$ & 0 \\
\hline $19 / 42$ & $\mathrm{Nl}$ & $\mathrm{NI}$ & $\mathrm{NI}$ & 0 & $\mathrm{NI}$ & 0 & ND & ND & ND & 0 \\
\hline $20 / 29$ & ND & 0 & $\mathrm{NI}$ & 0 & ND & ND & ND & ND & ND & $\mathrm{NI}$ \\
\hline $21 / 38$ & 0 & 0 & 0 & 0 & $\mathrm{NI}$ & $\mathrm{NI}$ & ND & $\mathrm{NI}$ & $\mathrm{NI}$ & $\mathrm{NI}$ \\
\hline $22 / 50$ & $\mathrm{Nl}$ & 0 & 0 & $\mathrm{NI}$ & $\mathrm{NI}$ & $\mathrm{NI}$ & ND & 0 & 0 & 0 \\
\hline $23 / 61$ & 0 & 0 & $\mathrm{NI}$ & 0 & $\mathrm{NI}$ & 0 & ND & 0 & $\mathrm{NI}$ & 0 \\
\hline \multicolumn{11}{|l|}{$\mathrm{ADH}$} \\
\hline $24 / 39$ & $\mathrm{NI}$ & $\mathrm{NI}$ & ND & $\mathrm{NI}$ & ND & ND & ND & ND & ND & 0 \\
\hline $25 / 47$ & ND & 0 & ND & $\mathrm{NI}$ & $\mathrm{NI}$ & $\mathrm{NI}$ & ND & ND & - & $\bullet$ \\
\hline $26 / 50$ & ND & 0 & 0 & $\mathrm{NI}$ & 0 & 0 & ND & ND & 0 & - \\
\hline $27 / 50$ & $\mathrm{NI}$ & 0 & 0 & $\mathrm{NI}$ & ND & $\mathrm{NI}$ & $\mathrm{NI}$ & ND & 0 & 0 \\
\hline $28 / 51$ & 0 & $\mathrm{NI}$ & ND & $\mathrm{NI}$ & ND & ND & ND & ND & ND & 0 \\
\hline $29 / 61$ & 0 & 0 & $\mathrm{NI}$ & 0 & $\mathrm{NI}$ & 0 & $\mathrm{NI}$ & 0 & $\mathrm{NI}$ & 0 \\
\hline
\end{tabular}

FIGURE 7. A summary of microsatellite loss-of-heterozygosity analysis in usual ductal hyperplasias, usual papillomas, and atypical ductal hyperplasias. MI, microsatellite instability; S409, S304, and so forth indicate loci of chromosome markers: D16S409, D16S304, and so forth; NI, not informative; ND, not done; $\bullet$, LOH; ○, no LOH.

TABLE 1. Cases

\begin{tabular}{|c|c|c|c|c|}
\hline \multirow{2}{*}{ Case } & \multirow{2}{*}{$\begin{array}{l}\text { Age, y } \\
\text { (1st/2nd) }\end{array}$} & \multirow{2}{*}{$\begin{array}{l}\text { Interval } \\
\text { between 1st } \\
\text { and 2nd } \\
\text { Surgery (y) }\end{array}$} & \multicolumn{2}{|c|}{ Histology of Tumor } \\
\hline & & & 1st Biopsy & $\begin{array}{c}\text { 2nd } \\
\text { Surgery }\end{array}$ \\
\hline 1 & $39 / 55$ & 16 & $\mathrm{ADH}$ & IDC, G3 \\
\hline 2 & $56 / 62$ & 5.5 & $\begin{array}{l}\text { Duct papillomatosis with } \\
\text { slight atypia }\end{array}$ & DCIS, LCIS \\
\hline 3 & $33 / 49$ & 16.1 & $\begin{array}{l}\text { Intraductal papilloma } \\
\text { with atypia }\end{array}$ & IDC, G3 \\
\hline 4 & $42 / 48$ & 5.8 & $\begin{array}{l}\text { Low-papillary } \\
\text { DCIS/atypical } \\
\text { papilloma }\end{array}$ & IDC, G2 \\
\hline 5 & $45 / 57$ & 11.2 & $\mathrm{ADH} /$ duct papillomatosis & DCIS \\
\hline 6 & $53 / 59$ & 5.3 & $\begin{array}{l}\text { Intraductal papilloma } \\
\text { with atypia }\end{array}$ & IDC, G2 \\
\hline 7 & $58 / 60$ & 2.7 & $\begin{array}{l}\text { Duct papillomatosis with } \\
\text { atypia }\end{array}$ & DCIS, IDC \\
\hline
\end{tabular}

$\mathrm{ADH}$, atypical ductal hyperplasia; IDC, invasive ductal carcinoma; G3, Grade 3; DCIS, ductal carcinomas in situ; LCIS, lobular; carcinoma in situ; G2, Grade 2.

group, $\mathrm{LOH}$ on $16 \mathrm{q}$ is mostly accompanied by the surplus $1 \mathrm{q} \operatorname{arm}(\mathrm{s})$ and clonal fusion(s) between the $1 \mathrm{q}$ and the residual fragment of chromosome 16, which generates a translocation $\operatorname{der}(16) \mathrm{t}(1 ; 16)$ (25-27).

The incidence of LOH on $16 \mathrm{q}$ was similar between carcinomas and atypical proliferative lesions of the breast but was very low or absent in usual ductal hyperplasias or usual papillomas. It was confirmed that there was a continuous spectrum between ADH/atypical papilloma and low-grade DCIS in terms of high incidence of $\mathrm{LOH}$ on 16q, as well as histological similarity. These atypical lesions would be situated as the earliest developmental stage of the group of low-grade DCIS/low- to intermediategrade IDC. The incidence of $\operatorname{der}(16) t(1 ; 16)$ formation in these atypical lesions remains to be elucidated.

The pattern of LOH on $16 q$ always differed between metachronous atypical proliferative lesions and carcinomas. In some cases, $\mathrm{LOH}$ on $16 \mathrm{q}$ was only detected in the later carcinoma, and the carcinoma might have occurred directly from residual $\mathrm{ADH} /$ atypical papilloma by the accumulation of other chromosome alterations, such as $\mathrm{LOH}$ on $16 q$, and subsequent inactivation of certain tumorsuppressor genes. However, in two patients, the later carcinoma was not considered to develop simply by the addition of chromosomal changes because $\mathrm{LOH}$ was only detected in the earlier atypical proliferative lesion. Examining the data from the seven cases, we could instead conclude that the atypical proliferative lesion and the carcinoma were usually clones, probably originated from a field with these clones, and that the former was not the direct precursor of the latter.

The $\mathrm{ADH}$ and atypical papilloma have been shown to be indicators of high risk of breast cancer $(3-5,7,28)$. However, these cancers occurred after the excision of those atypical lesions. Therefore, there might be a field of macroscopic size for cancer predisposition in the breast, or the whole breast might be the field for the predisposition. Even after the $\mathrm{ADH}$ or atypical papilloma was removed, the cell in the field could transform later to another $\mathrm{ADH} /$ atypical papilloma or to a malignancy. In such a field, certain predisposing factors might induce $\mathrm{LOH}$ on $16 \mathrm{q}$ and carcinogenesis in a relatively random manner, as well as ubiquitous proliferation of mammary gland cells.

$\mathrm{LOH}$ also has been shown to occur frequently in unremarkable mammary glands adjacent to cancer tissue (29). That result also suggested that there is a "localized predisposed region" from which the cancer arises, and in that study, genomic instability appeared to occur throughout the patch area of the predisposed region. Otherwise, the whole breast may be the predisposed region. The present result supports the idea that such a predisposed region existed in the present seven cases. The detection of $\mathrm{LOH}$ on specific chromosomal regions in a noncancerous epithelial component of mammary glands might be reasonable as the tool for monitoring the levels of genomic instability and cancer predisposition. Larger studies with analysis of a broader spectrum and other markers will be necessary to further our understanding of these elements of carcinogenesis in the breast. 
Acknowledgment: We thank Ms. Y. Yamauchi for preparing tissue sections.

\section{REFERENCES}

1. Page DL, Dupont WD, Rogers LW, Landenberger M. Intraductal carcinoma of the breast: follow-up after biopsy only. Cancer 1982;49:751-8.

2. Page DL, Dupont WD, Rogers LW, Jensen RA, Schuyler PA. Continued local recurrence of carcinoma 15-25 years after a diagnosis of low-grade ductal carcinoma in situ of the breast treated only by biopsy. Cancer 1995;76:1197-200.

3. Page DL, Anderson TJ, Rogers LW. Epithelial hyperplasia. In: Page DL, Anderson TJ, editors. Diagnostic histopathology of the breast. Edinburgh, Scotland: Churchill Livingstone; 1987: 120-56.

4. Dupont WD, Page DL. Risk factors for breast cancer in women with proliferative breast disease. N Engl J Med 1985; 312:146-51.

5. Haagensen CD, Bodian C, Haagensen DE Jr. Multiple intraductal papilloma. In: Breast cancer risk and detection. Philadelphia: WB Saunders; 1981:197-237.

6. Ohuchi N, Abe R, Kasai M. Possible cancerous change of intraductal papillomas of the breast: a 3-D reconstruction study of 25 cases. Cancer 1984;54:605-11.

7. Page DL, Salhany KE, Jensen RA, Dupont WD. Subsequent breast carcinoma risk after biopsy with atypia in a breast papilloma. Cancer 1996;78:258-66.

8. Sato T, Tanigami A, Yamakawa K, Akiyama F, Kasumi F, Sakamoto G, et al. Allelotype of breast cancer: cumulative allele losses promote tumor progression in primary breast cancer. Cancer Res 1990;50:7184-9.

9. Cleton-Jansen A-M, Moerland EW, Kuipers-Dijkshoon NJ, Callen DF, Sutherland GR, Hansen B, et al. At least two different regions are involved in allelic imbalance on chromosome arm 16q in breast cancer. Genes Chromosomes Cancer 1994;9:101-7.

10. Tsuda H, Fukutomi T, Hirohashi S. Pattern of gene alterations in intraductal breast neoplasms associated with histological type and grade. Clin Cancer Res 1995;1:261-7.

11. Chen T, Sahin A, Aldaz CM. Deletion map of Chromosome $16 \mathrm{q}$ in ductal carcinoma in situ of the breast: refining a putative tumor-suppressor gene region. Cancer Res 1996;56: 5605-9.

12. Lakhani SR, Collins N, Stratton MR, Sloane JP. Atypical ductal hyperplasia of the breast: clonal proliferation with loss of heterozygosity on chromosomes $16 \mathrm{q}$ and $17 \mathrm{p}$. J Clin Pathol 1995;48:611-5.

13. Lakhani SR, Slack DN, Hamoudi RA, Collins N, Stratton MR, Sloane JP. Detection of allelic imbalance indicates that a proportion of mammary hyperplasia of usual type are clonal, neoplastic proliferations. Lab Invest 1996;74:129-35.

14. O’Connell P, Pekkel V, Fuqua SA, Osborne CK, Clark GM, Allred DC. Analysis of loss of heterozygosity in 399 prema- lignant breast lesions at 15 genetic loci. J Natl Cancer Inst 1998;90:697-703.

15. Kasami M, Vnencak-Jones CL, Manning S, Dupont WD, Page DL. Loss of heterozygosity and microsatellite instability in breast hyperplasia. No obligate correlation of these genetic alterations with subsequent malignancy. Am J Pathol 1997; 150:1925-32.

16. Tsuda $\mathrm{H}$, Hirohashi S. Identification of multiple breast cancers of multicentric origin by histological observations and distribution of allele loss on Chromosome 16q. Cancer Res 1995;55:3395-8.

17. Noguchi S, Motomura K, Inaji H, Imaoka S, Koyama H. Clonal analysis of predominantly intraductal carcinoma and precancerous lesions of the breast by means of polymerase chain reaction. Cancer Res 1994;54:1849-53.

18. Amari M, Suzuki A, Moriya T, Yoshinaga K, Amano G, Sasano $\mathrm{H}$, et al. $\mathrm{LOH}$ analyses of premalignant and malignant lesions of human breast: frequent LOH in $8 p, 16 q$, and $17 q$ in atypical ductal hyperplasia. Oncol Rep 1999;6:1277-80.

19. Page DL, Rogers LW. Combined histologic and cytologic criteria for the diagnosis of mammary atypical ductal hyperplasia. Hum Pathol 1992;23:1095-7.

20. Page DL, Anderson TJ, Rogers LW. Carcinoma in situ. In: Page DL, Anderson TJ, editors. Diagnostic histopathology of the breast. Edinburgh, Scotland: Churchill Livingstone; 1987: 157-92.

21. Page DL, Anderson TJ, Sakamoto G. Infiltrating carcinoma: major histological types. In: Page DL, Anderson TJ, editors. Diagnostic histopathology of the breast. Edinburgh, Scotland: Churchill Livingstone; 1987:193-235.

22. Emmert-Buck MR, Bonner RF, Smith PD, Chuaqui RF, Zhuang Z, Goldstein SR, et al. Laser capture microdissection. Science 1996;274:998-1001.

23. Gyapay G, Morissette J, Vignal A, Dib C, Fizames C, Millasseau $\mathrm{P}$, et al. The 1993-94 Genethon human genetic linkage map. Nat Genet 1994;1993:7:246-339.

24. Doggett NA, Goodwin LA, Tesmer JG, Meincke LJ, Bruce DC, Clark LM, et al. An integrated physical map of human chromosome 16. Nature 1995;377(Suppl):335-65.

25. Dutrillaux B, Gerbault-Seureau M, Remvikos Y, Zafrani B, Prieur M. Breast cancer genetic evolution: I. Data from cytogenetics and DNA content. Breast Cancer Res Treat 1991; 19:245-55.

26. Pandis N, Jin Y, Gorunova L, Petersson C, Bardi G, Idvall I, et al. Chromosome analysis of 97 primary breast carcinomas: identification of eight karyotypic subgroups. Genes Chromosomes Cancer 1995;12:173-85.

27. Tsuda H, Takarabe T, Hirohashi S. Sites of Chromosome 16q breakage, frequently fused to chromosome 1q, correlate with aneusomies, histological grade, and type of human breast cancer. Int J Cancer 1999;84:381-7.

28. O'Connell P, Pekkel V, Fuqua S, Osborne CK, Allred DC. Molecular genetic studies of early breast cancer evolution. Breast Cancer Res Treat 1994;32:5-12.

29. Deng G, Lu Y, Zlotnikov G, Thor AD, Smith HS. Loss of heterozygosity in normal tissue adjacent to breast carcinomas. Science 1996;274:2057-9. 